\title{
Statistical Association of Basal Cell Keratins with Metastasis-Inducing Proteins in a Prognostically Unfavorable Group of Sporadic Breast Cancers
}

\author{
Suzete de Silva Rudland, ${ }^{+\dagger}$ Angela Platt-Higgins, ${ }^{* \dagger}$ \\ John H.R. Winstanley, ${ }^{\ddagger}$ Nigel J. Jones, ${ }^{\dagger}$ \\ Roger Barraclough, ${ }^{* \dagger}$ Christopher West, ${ }^{\S}$ \\ Joseph Carroll, ${ }^{\dagger}$ and Philip S. Rudland ${ }^{\star \dagger}$ \\ From the Cancer and Polio Research Fund Laboratories, ${ }^{*}$ the \\ Institute of Integrative Biology, ${ }^{\dagger}$ and the Institute of Psychology, \\ Health and Society, ${ }^{\circledR}$ Faculty of Health and Life Sciences, \\ University of Liverpool, Liverpool; and the Department of \\ Surgery, ${ }^{\ddagger}$ Royal Bolton Hospital, Bolton, United Kingdom
}

Two subgroups of invasive breast carcinomas have been identified with a poor prognosis in different patient cohorts: the basal-like category and the subgroup containing proteins capable of inducing metastasis in experimental rodents, the metastasis-inducing proteins (MIPs). Here we identify by immunohistochemical staining for cytokeratin CK5/6 or CK14 the basal-like subgroup in a set of 297 primary invasive breast carcinomas in which the staining profile for the MIPs S100A4, osteopontin, anterior gradient-2, and S100P has already been established. Monoclonal antibodies to CK5/6 or CK14 specifically stain $31 \%$ to $34 \%$ of the primary carcinomas. These positively stained tumors are highly significantly associated with premature death of the patient (Wilcoxon statistics, $P<0.0001$ ), the increased relative risk being approximately 5.6 -fold. Positive staining for either cytokeratin is very significantly associated with that for each of the four MIPs separately and with loss of staining for the Fanconi anemia protein FANCD2 (corrected Fisher's exact test, $\boldsymbol{P}<0.0007$ ). There is no significant correlation with the remaining tumor variables tested, including staining for the estrogen receptor $\alpha$, progesterone receptor, and c-erbB-2. These results show that the basal cytokeratin-like carcinomas contain many of the MIPs and that these may arise by their selection for tumors with an inherent deficiency in the FANC/BRCA pathway of DNA repair. (Am J Pathol 2011, 179:1061-1072; DOI: 10.1016/j.ajpath.2011.04.022)
Breast cancer, which usually develops from the terminal ductal lobular units, ${ }^{1}$ can be divided into two main groups, with ductal carcinomas accounting for $80 \%$ to $90 \%$ of breast cancers and lobular carcinomas accounting for $5 \%$ to $15 \%$; the remainder represents less common, special types of cancer. ${ }^{2}$ Nonetheless, the heterogeneous nature of invasive carcinomas has previously caused difficulties in predicting prognosis. Recently, Sorlie et $\mathrm{al}^{3}$ showed that invasive breast cancer can be divided into five clear molecular subgroups with common features, using microarray gene expression profiling: luminal A, luminal B, HER2-overexpressing, normal breast-like, and basal-like categories. The luminal gene expression (GE) subgroups $A$ and B show some but not complete similarity to expression of mRNAs found in normal luminal epithelial cells and are predominantly immunohistochemically $(\mathrm{IHC})$ positive for the estrogen receptor $\alpha(\mathrm{ER} \alpha)$; the HER2 GE subgroup also produces more of the $\mathrm{IHC}$-detectable c-erbB-2 receptor protein; and the normal GE subgroup expresses genes completely characteristic of normal luminal epithelial cells, including lower levels of ER $\alpha$ than in luminal subgroups A and $\mathrm{B}$. The basal-like subgroup, in contrast, produces more of the IHC-detectable stratified epithelial cytokeratins, including CK5/6 and CK14, ${ }^{3,4}$ which are commonly found in basal epithelial and some myoepithelial cells of the breast. $^{5}$ Nonetheless, the basal-like GE subgroup lacks other markers, such as smooth muscle actin/myosin, that are present in fully differentiated myoepithelial cells. ${ }^{6,7}$ The presence of expression signatures and protein markers CK5/6 and CK14 of the basal-like phenotype have repeatedly been shown to be associated with high-grade breast cancers

Supported by the Cancer and Polio Research Fund, Wirral, Cheshire, United Kingdom.

Accepted for publication April 5, 2011.

Supplemental material for this article can be found at http://ajp. amjpathol.org or at doi: 10.1016/j.ajpath.2011.04.022.

Address reprint requests to Professor Philip S. Rudland, Ph.D., Institute of Integrative Biology, Biosciences Building, Crown Street, University of Liverpool, Liverpool L69 3BX, UK; or Dr. Suzete de Silva Rudland, M.B.B.Chir., Ph.D., T.C.B.C., Institute of Integrative Biology, Biosciences Building, Crown Street, University of Liverpool, Liverpool L69 7ZB, UK. E-mail: sdsrudland@yahoo.com or sdesilva@liv.ac.uk. 
and sometimes with poor patient outcomes. ${ }^{5,8-12}$ Because the role of stratified keratins in cancer is poorly understood, it is not clear why they should be associated with highgrade tumors and poor patient outcomes.

In parallel with the search for markers of patient outcome in human breast cancer, genes have been identified that, if transfected into and overexpressed in a benign rat mammary epithelial stem cell line ${ }^{13}$ and the resultant transfectants injected into the mammary fat pad of syngeneic rats, induce these same cells to metastasize in vivo. Four of these metastasis-inducing genes code for the proteins S100A4, ${ }^{14}$ osteopontin (OPN),${ }^{15}$ anterior gradient-2 (AGR2), ${ }^{16}$ and S100P. ${ }^{17}$ The expression of these four metastasis-inducing proteins (MIPs) in the primary breast tumor is highly correlated and each is separately associated with early patient death from metastatic human breast cancer. ${ }^{17-20}$

It has been suggested that the MIP-coordinated expression is linked, in part, to a failure of the Fanconi anemia (FA)/BRCA tumor suppressor DNA pathway, ${ }^{21}$ because the coordinated expression of MIPs and early patient death is also highly correlated with lack of the IHC-detectable FANCD2, a pivotal component in the FA/ BRCA pathway. ${ }^{22}$ Thus, the combination of overexpression of the four MIPs and lack of FANCD2 in the primary carcinomas also defines a subgroup of breast cancer patients with a poor outcome. Because there is no association of these MIPs or lack of FANCD2 with c-erbB$2,{ }^{17-22}$ the most likely poor-prognosis category to which they might be related is that of the basal-like subgroup of breast cancers. To test this hypothesis, we have immunohistochemically stained primary carcinomas from a group of breast cancer patients for the basal cell markers CK5/6 and CK14, to identify an IHC-defined basal-like subgroup of breast cancers and assess their relationship to patient survival and to the MIPs and FANCD2 in the same set of primary breast cancers.

\section{Materials and Methods}

\section{Patients and Specimens}

A retrospective study was made using samples of 297 primary tumors from unselected breast cancer patients who presented at general surgery clinics in the Merseyside Region between 1976 and 1982. They were treated surgically by mastectomy with sampling of axillary lymph nodes $(17 \%)$ or modified radical mastectomy $(83 \%)$ alone; no adjuvant therapy was given, including no hormonal therapy. ${ }^{17-19}$ Only patients with operable breast cancer $\left(T_{1-4}, N_{0-1}, M_{0}\right)$ were included in the study. ${ }^{18,19,22}$ The menopausal status, treatment, tumor type, tumor size, histological grade, and lymph node status were as described previously. ${ }^{20}$ Patient age ranged from 30 to 81 years (mean, 60.3 years), and all patients had invasive carcinoma (92.3\% invasive ductal; $6.1 \%$ invasive lobular; $1.6 \%$ special type of invasive breast carcinoma, mucinous and medullary). The mean patient follow-up duration was 16 years (range, 14 to 20 years), yielding a mean survival time of 9.3 years. Summary of overall patient survival and of the significant pathological prognostic variables over 20 years has been reported previously. ${ }^{22}$ Normal breast tissue was obtained as described previously. ${ }^{18}$ Approval was obtained from the Liverpool Ethics Committee, and the patient data were anonymized as described previously. ${ }^{22}$ Samples were fixed originally in neutral buffered formalin and embedded in paraffin wax, as described previously. ${ }^{18}$

\section{IHC Staining}

Histological sections cut at $4 \mu \mathrm{m}$ were mounted on 3-aminopropyltriethoxysilane (APES)-coated slides, dewaxed in xylene, and rehydrated through ethanol to water. ${ }^{18}$ To enhance immunocytochemical staining, antigen retrieval was performed by microwaving sections at $85 \mathrm{~W}$ for 15 minutes in $10 \mathrm{mmol} / \mathrm{L}$ Tris-EDTA buffer, $\mathrm{pH}$ 9.0, for CK5/6 or $10 \mathrm{mmol} / \mathrm{L}$ citrate buffer, $\mathrm{pH}$ 6.0, for CK14. Endogenous peroxidase was blocked with $0.05 \%(\mathrm{v} / \mathrm{v})$ $\mathrm{H}_{2} \mathrm{O}_{2}$ in methanol. ${ }^{18}$ For staining for $\mathrm{CK} 5 / 6$, slides were incubated for 3 hours at room temperature with mouse monoclonal antibody (mAb) to CK5/6 diluted 1:500 in $0.5 \%(\mathrm{w} / \mathrm{v})$ bovine serum albumin in PBS (MAB1620; Chemicon, Hampshire, UK; Temecula, CA). Bound antibody was detected using a Dako EnVision+ systemhorseradish peroxidase kit (DakoCytomation, Glostrup, Denmark; Carpinteria, CA). For staining for CK14, slides were incubated for 2.5 hours at room temperature with mouse mAb to CK14 diluted 1:30 in 0.05\% (w/v) bovine serum albumin in PBS (LL002, ab7800; Abcam, Cambridge, UK). Bound antibody was detected by incubation with biotinylated sheep anti-mouse for 1 hour diluted 1:200 (Amersham; GE Healthcare, Little Chalfont, UK), followed by a commercially available ABComplex/horseradish peroxidase for 1 hour (DakoCytomation). Bound antibodies were visualized by brown staining with diaminobenzidine (DAB; Sigma-Aldrich, Poole, UK; St. Louis, MO). Nuclei were counterstained blue with Mayer's hemalum. Blocked mAb to CK14 was prepared by mixing $500 \mu \mathrm{g} / \mathrm{mL}$ of a synthetic peptide prepared in-house (sequence CDGKVSTHEQVLRTKN; see Purkis et $\mathrm{al}^{23}$ ). Double IHC staining for CK5/6 and S100A4 was conducted sequentially using the above enhanced horseradish peroxidase-diaminobenzidine-labeled polymer system for CK5/6 and then alkaline phosphatase Permanent Red chromogen-labeled polymer system for S100A4, ${ }^{24}$ with the Dako Envision G/2 Doublestain system rabbit/mouse (Dako) giving brown or red/pink stains, respectively. The histological slides were mounted in Glycergel mounting medium (Dako). Western blots of breast carcinomas have verified the specificity of both cytokeratin mAbs used, as described previously. ${ }^{8,9}$ Photographs were recorded in a Reichert light microscope fitted with a Wratten 44 light blue-green filter or Hoya (Tokyo, Japan) 80A filter on Ilford PANF Plus (50 ASA) black and white film ${ }^{17}$ or Kodacolor Plus (200 ASA) color film, respectively.

Sections were analyzed and scored using light microscopy by three independent observers (S.de S.R., A.P.-H., and P.S.R.), including a qualified pathologist (P.S.R.), according to the percentage of tumor cells showing positive IHC staining. The percentage of stained tumor cells 
was recorded from two well-separated sections of each specimen, with 10 fields per section at $\times 200$ magnification and a minimum of 200 cells per field. ${ }^{18}$ Staining for CK5/6 and CK14 was evaluated in three classes, as described previously: unstained, $<1 \%$; borderline, $1 \%$ to $5 \%$; and positively stained, $>5 \%$ of the carcinoma cells stained. ${ }^{17}$ Any disagreements were resolved by re-examination of the disputed slides and, if agreement was still not reached, by subsequent recutting and restaining fresh sections of the same area.

$\mathrm{IHC}$ staining data on the same group of patients had been obtained previously for $\mathrm{S} 100 \mathrm{~A} 4,{ }^{18}$ OPN, ${ }^{19}$ c-erbB-2, ER $\alpha$, progesterone receptor (PgR), pS2, p53, ${ }^{25}$ and $\mathrm{S}_{100 \mathrm{P}^{17}}$ using a $5 \%$ cutoff to differentiate between the unstained and positively stained carcinomas; for cathepsin $D^{25}$, AGR2, ${ }^{20}$ and FANCD2 ${ }^{22}$ a $1 \%$ cutoff was used. These cutoffs yielded the highest risk factors between the two groups in this set of patients (see Supplemental Table S1 at $h$ ttp://ajp.amjpathol.org). ${ }^{17,20}$ The 5\% cutoffs for ER $\alpha$ and c-erbB-2 staining approximated but did not replicate the standard cutoffs used in UK clinical practice ${ }^{26,27}$ and in the REMARK study, ${ }^{28}$ as described previously. ${ }^{22}$ Western blots of breast carcinomas verified the specificity of both cytokeratin mAbs used, as described previously. ${ }^{8,9}$ IHC staining for CK5/6, CK 14 , S100A4, S100P, OPN, AGR2 and FANCD2 was repeated for a few positive (or negative, for FANCD2) and borderline staining tumors, and the same focal (for borderline) or enhanced (for positive) staining microscopic fields $\left(\times 200\right.$ magnification, $0.78 \mathrm{~mm}^{2}$ ) were scored for the percentage of stained carcinoma cells from two adjacent histological sections, counted five times for each of these antigens (400 to $600 \mathrm{cells} /$ field). This scoring was repeated in the same immediately adjacent field for each antigen.

\section{Statistical Methods}

The association of staining for CK5/6 or CK 14 in primary breast carcinomas with patient survival was calculated from life tables constructed from survival data using Kaplan-Meier plots and was analyzed by generalized Wilcoxon (Gehan) statistics. ${ }^{18}$ Patients who died of causes other than cancer were censored. Unadjusted relative risk (RR) for survival with 95\% confidence interval (Cl) was calculated using Cox's univariate analysis. ${ }^{25}$

The association of IHC staining for CK5/6 or CK 14 with other tumor variables in this group of patients was assessed by cross-tabulation using Fisher's exact test, twosided values of probability were given. ${ }^{19}$ The cutoff value between unstained and positively stained for $\mathrm{CK} 5 / 6$ and for CK14 was usually set at $1 \%$, as described under Results; for the other proteins, it was set at $1 \%$ or $5 \%$, as described above. For multiple comparisons, the resulting $P$ values were subjected to Holm-Bonferroni correction, calculated as $1-(1-P)^{n}$, where $n$ is the number of tumor variables. For overall association or clustering between staining for $\mathrm{CK} 5 / 6$ and CK14 using a $1 \%$ cutoff, for the four MIPs, and for no staining for FANCD2, Kendall's coefficient of concordance $(W)$ was calculated to extend rank correlation to seven variables. ${ }^{29}$ Significance of the difference in pairs of means was calculated using Student's two-sided $t$-test; occasionally the assumption of equal variance did not hold when the $F$-test for comparison of variance was significantly different; in such cases, the approximate $t$-test for unequal variance was used.

To determine whether the association of patient survival with $\mathrm{CK} 5 / 6$ or CK 14 was independent of other tumor variables found to be significantly associated in this group of patients, multivariate analyses were performed using Cox's proportional hazards model on 137 patients with full data sets. ${ }^{17}$ Incomplete data arose mainly from lack of sampling or location of lymph nodes originally and to a lesser extent to lack of sufficient malignant material remaining in some paraffin blocks to obtain satisfactory data. This analysis treated variables as categorical in positively and unstained groups defined above and used the forward stepwise Wald method, which generated the most significant variable at each step assuming proportional hazards. Data analysis was performed using Excel 2007 (Microsoft, Redmond, WA) and SPSS version 16.0 (SPSS, Chicago, IL).

\section{Results}

\section{IHC Staining of Breast Carcinomas for CK5/6 and CK14}

Normal breast tissues were incubated with $\mathrm{mAb}$ to $\mathrm{CK} 5 / 6$ or with $\mathrm{mAb}$ to $\mathrm{CK} 14$, but the majority of epithelial cells in the ducts remained unstained, with staining evident only in myoepithelial/basal or occasionally in suprabasally situated epithelial-like cells (Figure 1A; see also Supplemental Figure S1A at http://ajp.amjpathol.org). Some areas of epithelial hyperplasia also contained CK5/6 and CK14 staining epithelial cells (data not shown). On examination of 297 breast carcinomas for CK5/6, 204 of them $(68.7 \%)$ were unstained (Figure 1B; see also Supplemental Figure S1B at http://ajp.amjpathol.org), 84 (28.3\%) showed borderline staining (Figure 1C; see also Supplemental Figure $\mathrm{S} 1 \mathrm{C}$ at $h$ ttp://ajp.amjpathol.org), and the remaining 9 (3.0\%) showed positive staining (Figure 1D; see also Supplemental Figure S1D at http://ajp. amjpathol.org). When the same breast carcinomas were examined for CK14, 195 of them (65.7\%) were unstained, $50(16.8 \%)$ showed borderline staining, and the remaining $52(17.5 \%)$ showed positive staining (Figure 1E; see also Supplemental Figure S1E at $h$ ttp://ajp.amjpathol.org). In both cases, there was no staining of stromal cells, and the staining was confined to the cytoplasm (Figure 1F; see also Supplemental Figure S1F at $h$ ttp://ajp.amipathol.org). IHC staining for $\mathrm{CK} 14$ was abolished by prior incubation of the mAb to CK14 with our synthetic immunizing peptide (Figure $1, G$ and $H$; see also Supplemental Figure S2, A and $\mathrm{B}$, at http://ajp.amjpathol.org). The assessment of the staining class was made only on malignant cells.

For the purpose of most of the analyses, the borderline stained carcinomas ( $1 \%$ to $5 \%$ of carcinoma cells stained) were combined with the positively stained carcinomas ( $>5 \%$ of carcinoma cells stained), giving a group of positively stained carcinomas showing $>1 \%$ of 

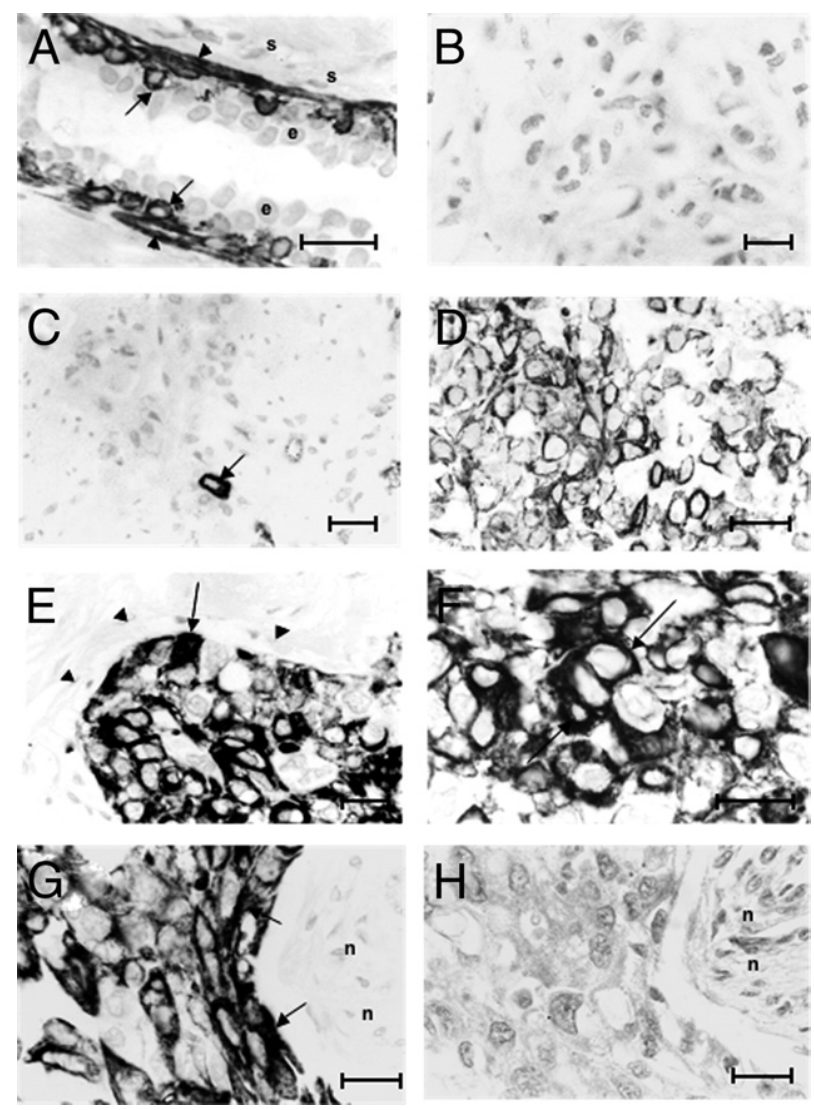

Figure 1. IHC staining of human breast tissues for cytokeratins CK14 and CK5/6. A: Incubation of normal breast duct tissue with antibody to CK14 shows staining of myoepithelial/basal cells (arrowheads) and of occasional suprabasal epithelial-like cells (arrows); most epithelial cells (e) and the adjacent stromal cells (s) were unstained. B: Invasive carcinoma stained for CK5/6 shows no IHC staining. C: Invasive carcinoma stained for CK5/6 shows borderline staining of the occasional malignant cell (arrow). D: Invasive carcinoma stained for $\mathrm{CK} 5 / 6$ shows positive staining for malignant cells. E: Invasive carcinoma stained for CK14 shows positive staining for malignant cells (arrow); host fibroblasts and blood vessels were unstained (arrowheads). F: A different section of the invasive carcinoma in $\mathrm{E}$, at a higher magnification, illustrates cytoplasmic staining (arrows) in malignant cells stained for CK14. G and $\mathbf{H}$ : Adjacent sections of the same invasive carcinoma. Tissue incubated with mAb to CK14 (G) shows strong staining of the carcinoma cells; there is no staining with the same mAb preincubated with our synthetic peptide (described under Materials and Methods) (H); necrotic areas $(\mathrm{n})$ were unstained under both conditions. Original magnification: $\times 400(\mathbf{B}, \mathbf{C}$, and $\mathbf{E}) ; \times 500(\mathbf{D}, \mathbf{G}$, and $\mathbf{H}) ; \times 620(\mathbf{A}$ and $\mathbf{F})$. Scale bars $=25 \mu \mathrm{m}$.

the malignant cells stained for either cytokeratin. This left the remaining group as a clearly unstained carcinoma group, with $<1 \%$ of the malignant cells stained for the cytokeratins (see Supplemental Table S2 at http://ajp. amjpathol.org). There was a high level of consistency in scoring for the mAb to CK5/6 and to CK14 between the two observers, with disagreement in $6.4 \%$ and $5.9 \%$ of cases, corresponding to $\kappa$ scores of 0.82 and 0.85 , respectively. Intratumor heterogeneity was $6.4 \%$ and $6.9 \%$, respectively, for two sections of the same carcinoma.

\section{IHC Staining for Cytokeratins and Overall Patient Survival}

To determine whether there was any association between staining for CK5/6 or CK14 and duration of survival of patients with breast cancer, Kaplan-Meier survival curves were plotted for patient groups with tumors classified as unstained, borderline, or positively stained for either cytokeratin. Overall, there was a significant difference using Wilcoxon (Gehan) statistics for staining for either CK5/6 or for CK14. However, differences occurred only between patients with no staining and borderline stained tumors (see Supplemental Table S2 at http://ajp.amjpathol.org). The 297 patients were therefore separated into two categorical groups, using a cutoff of $1 \%$ stained carcinoma cells. Only $10 \%$ survived with positively stained tumors for CK5/6, compared with $74 \%$ who survived with unstained tumors (see Supplemental Table S2 at http:// ajp.amjpathol.org). This difference was highly significant, with a median duration of survival of 53 versus $>228$ months (Figure 2A). Similarly, only $12 \%$ survived with positively stained tumors for CK14, compared with $75 \%$
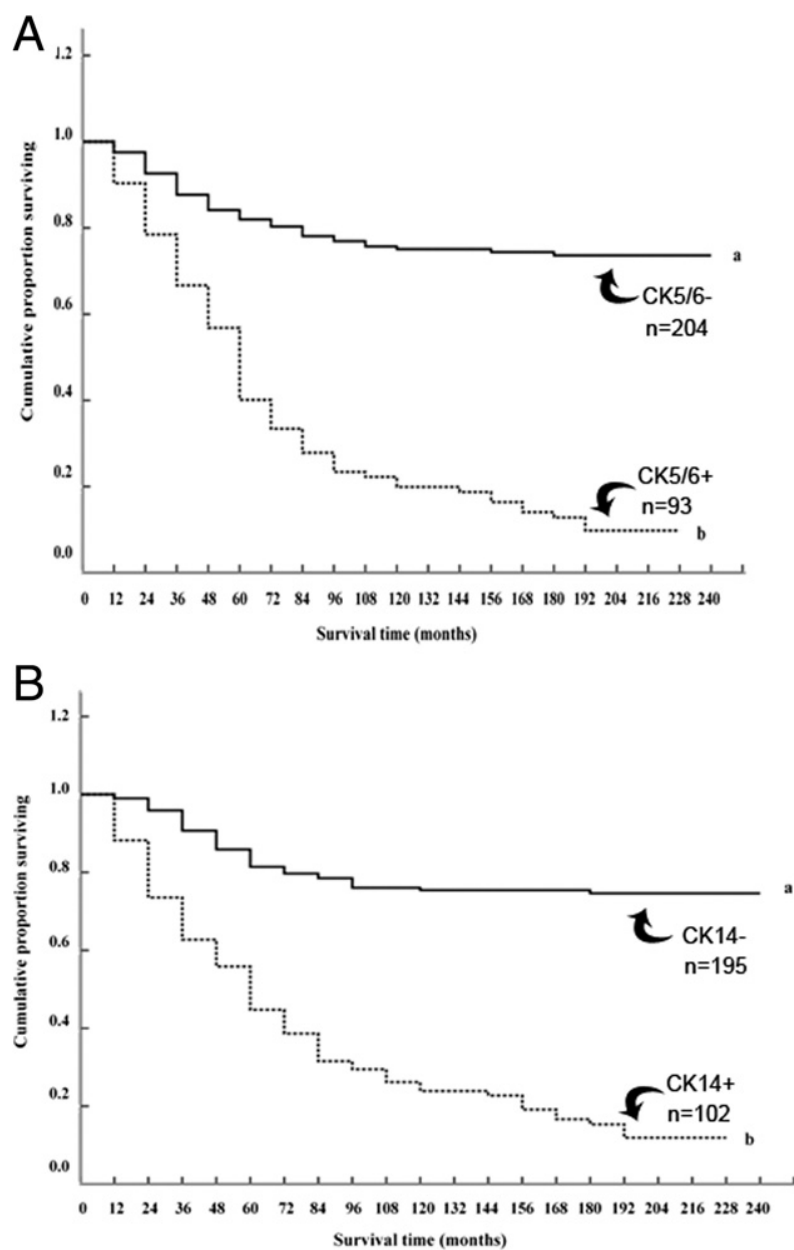

Figure 2. Association of IHC staining for cytokeratins CK5/6 and CK14 with overall duration of patient survival. A: The cumulative proportion of surviving patients as a percentage of the total for each year after presentation for patients with carcinomas classified as unstained (set a, solid line) or positively stained (set b, dotted line) for CK5/6. There were 154 censored observations in set $\mathbf{a}$ ( 53 dead of other causes) and 12 in set $\mathbf{b}$ (three dead of other causes). The two curves were highly significantly different (Wilcoxon statistic $\left.\chi^{2}=72.81,1 \mathrm{df}, P<0.0001\right)$. B: The cumulative proportion of surviving patients with carcinomas classified as unstained (set $\mathbf{a}$, solid line) or positively stained (set b, dotted line) for CK14. There were 149 censored observations in set $\mathbf{a}$ ( 48 dead of other causes) and 17 in set $\mathbf{b}$ (eight dead of other causes). The two curves were highly significantly different (Wilcoxon statistic $\left.\chi^{2}=78.63,1 \mathrm{df}, P<0.0001\right)$. 
Table 1. Association of IHC Staining for CK $5 / 6$ with Other Tumor Variables

\begin{tabular}{|c|c|c|c|c|}
\hline \multirow[b]{2}{*}{ Tumor variable* } & \multicolumn{2}{|c|}{ CK5/6 [no. (\%)] $]^{\dagger}$} & \multicolumn{2}{|c|}{ Statistical significance ${ }^{\ddagger}$} \\
\hline & Unstained & Stained & Uncorrected & Corrected \\
\hline $\mathrm{LN}^{-}$ & $82(56)$ & $32(43)$ & 0.065 & 0.66 \\
\hline $\mathrm{LN}^{+}$ & $64(44)$ & $43(57)$ & & \\
\hline Grade I + II & $142(78.5)$ & $57(65.5)$ & 0.026 & 0.34 \\
\hline Grade III & $39(21.5)$ & $30(34.5)$ & & \\
\hline Tumor, $<5 \mathrm{~cm}$ & $158(79)$ & $66(74)$ & 0.45 & 1.00 \\
\hline Tumor, $>5 \mathrm{~cm}$ & $43(21)$ & $23(26)$ & & \\
\hline $\mathrm{OPN}^{-}$ & $88(46)$ & $6(7)$ & $<0.0001$ & $<0.0001$ \\
\hline $\mathrm{OPN}^{+}$ & $105(54)$ & $83(93)$ & & \\
\hline c-erbB-2 ${ }^{-}$ & $154(78)$ & $68(74)$ & 0.46 & 1.00 \\
\hline c-erbB-2 ${ }^{+}$ & $44(22)$ & $24(26)$ & & \\
\hline c-erbB-3- & $86(43)$ & $31(34)$ & 0.16 & 0.93 \\
\hline c-erbB-3 ${ }^{+}$ & $112(57)$ & $60(66)$ & & \\
\hline $\mathrm{S} 100 \mathrm{~A} 4^{-}$ & $145(72)$ & $32(34)$ & $<0.0001$ & $<0.0001$ \\
\hline${\mathrm{S} 100 \mathrm{~A} 4^{+}}^{+}$ & $57(28)$ & $61(66)$ & & \\
\hline $\mathrm{S}^{100 \mathrm{P}^{-}}$ & $97(54)$ & $21(27)$ & $<0.0001$ & 0.00069 \\
\hline $\mathrm{S}_{100 \mathrm{P}^{+}}$ & $82(46)$ & $58(73)$ & & \\
\hline $\mathrm{PgR}^{-}$ & $117(61)$ & $57(63)$ & 0.79 & 1.00 \\
\hline $\mathrm{PgR}^{+}$ & 76 (39) & $34(37)$ & & \\
\hline $\mathrm{p} 53^{-}$ & $120(59)$ & $52(56)$ & 0.61 & 1.00 \\
\hline${\mathrm{p} 53^{+}}^{+}$ & $82(41)$ & $41(44)$ & & \\
\hline Cathepsin $D^{-}$ & 30 (19) & $11(15)$ & 0.58 & 1.00 \\
\hline Cathepsin $\mathrm{D}^{+}$ & $129(81)$ & $63(85)$ & & \\
\hline $\mathrm{pS}^{-}$ & $116(57)$ & $53(58)$ & 1.00 & 1.00 \\
\hline $\mathrm{pS} 2^{+}$ & $86(43)$ & $38(42)$ & & \\
\hline $\mathrm{ER} \alpha^{-}$ & $93(46)$ & $44(48)$ & 0.80 & 1.00 \\
\hline $\mathrm{ER} \alpha^{+}$ & $109(54)$ & $47(52)$ & & \\
\hline $\mathrm{AGR}^{-}$ & $84(43.5)$ & $8(9)$ & $<0.0001$ & $<0.0001$ \\
\hline AGR2 $^{+}$ & $109(56.5)$ & $78(91)$ & & \\
\hline FANCD2 $^{-}$ & $47(25)$ & $56(64)$ & $<0.0001$ & $<0.0001$ \\
\hline FANCD2 $^{+}$ & $138(75)$ & $32(36)$ & & \\
\hline CK14- & $161(79)$ & $34(37)$ & $<0.0001$ & $<0.0001$ \\
\hline $\mathrm{CK} 14^{+}$ & $43(21)$ & 59 (63) & & \\
\hline
\end{tabular}

*LN, lymph node with (+) tumor or without (-) tumor deposits; grade, histological grades I and II versus histological grade III; tumor size $>5 \mathrm{~cm}$ versus $<5 \mathrm{~cm}$ in diameter; other tumor variables, presence $(+)$ or absence $(-)$ of IHC staining for molecular variables using $5 \%$ cutoff for $(+)$ versus $(-)$ staining class for OPN (osteopontin), ER $\alpha$ (estrogen receptor $\alpha$ ), PgR (progesterone receptor), S100P , S100A4, c-erbB-2, c-erbB-3, p53, pS2, and using a 1\% cutoff for $(+)$ versus $(-)$ staining for FANCD2, AGR2, cathepsin D, CK14.

${ }^{\dagger}$ Number (and percentage) of patients with carcinomas classified as stained or unstained for CK5/6 using a 1\% cutoff.

FProbability $P$ from Fisher's exact test (two sided values), either uncorrected or corrected using the Holm-Bonferroni correction calculated as 1 - (1 $P)^{n}$, where $n=16$ (see further under Materials and Methods).

with unstained tumors. This difference was also highly significant, with a median duration of survival of 54 versus $>228$ months (Figure 2B). The differences between these curves first became statistically significant for either cytokeratin after 1 year $\left(\mathrm{CK} 5 / 6 \chi^{2}=7.11,1 \mathrm{df}, P=0.008\right.$; CK14 $\left.\chi^{2}=17.16,1 \mathrm{df}, P<0.001\right)$. When patients with tumors unstained for either cytokeratin were compared with those with singly or doubly stained tumors for $\mathrm{CK} 5 / 6$ and CK14, they were found to be highly significantly different (see Supplemental Figure S3 at http://ajp. amjpathol.org). However, patients with tumors showing positive staining for only one cytokeratin were not significantly different from each other or from those showing positive staining for both cytokeratins (see Supplemental Figure S3 at $h$ ttp://ajp.amjpathol.org).

\section{Association of Cytokeratins with Other Tumor Variables}

The results of the $\mathrm{IHC}$ staining for $\mathrm{CK} 5 / 6$ and $\mathrm{CK} 14$ using a $1 \%$ cutoff were cross-tabulated against pathological variables: nodal status, histological grade (I, II versus III), tumor size $\left(T_{1}\right.$ and $T_{2}$ versus $T_{3}$ and $\left.T_{4}\right)$, and $I H C$ staining for molecular variables (OPN, c-erbB-2, c-erbB-3, S100A4, S100P, PgR, p53, cathepsin D, pS2, ER $\alpha$, AGR2, and FANCD2) taken from the same carcinoma samples. These other variables have been reported to have an effect on survival times in the same set of patients (see Supplemental Table S1 at $h$ ttp://aip.amipathol.org). Of the pathological variables, only high histological grade (grade III) showed any significant association with staining for CK5/6 (Fisher's exact test, $P=0.026$ ), but even this association was lost when corrected for chance occurrence in multiple comparisons (corrected $P=0.34$ ) (Table 1). When grades I and II were separated, there was a small stepwise increase in staining for either cytokeratin from $25 \%$ to $30 \%$ for grade I, through $31 \%$ to $36 \%$ for grade II to $38 \%$ to $44 \%$ for grade III tumors, but no significant stepwise correlations between staining and grade (Table 2). In contrast, there was a statistically significant association of carcinomas staining positive for CK5/6 (Table 1) or for CK14 (Table 3) with positive staining for the four MIPs [OPN $(P<0.0001)$, S100A4 $(P<$ $0.0001)$, S100P $(P \leq 0.0007)$, AGR2 $(P<0.0001)]$ and 
1066 Rudland et al

AJP August 2011, Vol. 179, No. 2

Table 2. Immunocytochemical Staining for Cytokeratins with Different Histological Grades of Breast Tumor

\begin{tabular}{|c|c|c|c|c|c|c|c|c|}
\hline \multirow{2}{*}{$\begin{array}{c}\text { Histological } \\
\text { grade }\end{array}$} & \multicolumn{2}{|c|}{ CK5/6 [no. (\%)] } & \multicolumn{2}{|c|}{ Statistical significance* $^{*}$} & \multicolumn{2}{|c|}{ CK14 [no. (\%)] } & \multicolumn{2}{|c|}{ Statistical significance $^{*}$} \\
\hline & Unstained & Stained & Contrast & $P$ value & Unstained & Stained & Contrast & $P$ value \\
\hline । & $52(28.7)$ & $17(19.5)$ & | vs || & 0.412 & $48(27.6)$ & $21(22.3)$ & | vs || & 0.437 \\
\hline$\|$ & $90(49.7)$ & $40(46)$ & II vs III & 0.087 & $83(47.7)$ & $47(50)$ & II vs III & 0.878 \\
\hline III & $39(21.5)$ & $30(34.5)$ & I vs III & 0.031 & $43(24.7)$ & $26(27.7)$ & | vs III & 0.473 \\
\hline
\end{tabular}

Number (and percentage) of patients with carcinomas classified as stained or unstained for CK5/6 or CK14 using a $1 \%$ cutoff.

*Probability $P$ from Fisher's exact test (two sided values).

inversely with that for FANCD2 $(P<0.0001)$ with or without the Holm-Bonferroni correction for multiple comparisons (Tables 1 and 3 ). There was also a highly significant association of staining between these two cytokeratins $(P<0.0001)$ (Tables 1 and 3 ).

For the remaining molecular variables tested, positive staining for c-erbB-2, c-erbB-3, ER $\alpha, \mathrm{PgR}, \mathrm{p} 53$, cathep$\sin \mathrm{D}$, and pS2 showed no significant association with positive staining for $\mathrm{CK} 5 / 6$ or for $\mathrm{CK} 14$ in this group of patients (Tables 1 and 3 ). The highly significant association of staining for CK14 and MIPs/FANCD2 was maintained for staining cutoffs set at $5 \%$ as well as for $1 \%$ (corrected $P \leq 0.016)$. There was also a strong association of staining for $\mathrm{CK} 5 / 6$ or $\mathrm{CK} 14$ with that for the four MIPs and inversely for FANCD2 in the ER $\alpha$-negative (corrected $P \leq 0.005$, except $\mathrm{S} 100 \mathrm{P}$ for $\mathrm{CK} 5 / 6, P=0.22$ ), the ER $\alpha$-positive (corrected $P \leq 0.005$, except FANCD2 for $\mathrm{CK} 14, P=0.06)$ and the $\mathrm{ER} \alpha, \mathrm{PgR}, \mathrm{c}-\mathrm{erbB}-2$ negative (triple negative ${ }^{30}$ ) (corrected $P<0.05$ for $\mathrm{CK} 5 / 6$ or $\leq 0.005$ for CK14) staining carcinomas (see Supplemental Table S3 at http://ajp.amjpathol.org). There was no significant association of triple-negative carcinomas and staining for the four MIPs or FANCD2 (corrected $P \geq$ 0.38), excepting an inverse association with staining for

Table 3. Association of IHC Staining for CK14 with Other Tumor Variables

\begin{tabular}{|c|c|c|c|c|}
\hline \multirow[b]{2}{*}{ Tumor variable* } & \multicolumn{2}{|c|}{ CK14 [no. (\%) $]^{\dagger}$} & \multicolumn{2}{|c|}{ Statistical significance ${ }^{\ddagger}$} \\
\hline & Unstained & Stained & Uncorrected & Corrected \\
\hline $\mathrm{LN}^{-}$ & $78(54)$ & $36(47)$ & 0.32 & 1.00 \\
\hline $\mathrm{LN}^{+}$ & $66(46)$ & $41(53)$ & 0.06 & \\
\hline Grade I + II & $131(75)$ & $68(72)$ & 0.66 & 1.00 \\
\hline Grade III & $43(25)$ & $26(28)$ & & \\
\hline Tumor $<5 \mathrm{~cm}$ & $148(77.5)$ & $76(77)$ & 0.88 & 1.00 \\
\hline Tumor $>5 \mathrm{~cm}$ & $43(22.5)$ & 23 (23) & & \\
\hline $\mathrm{OPN}^{-}$ & $85(46)$ & $9(9)$ & $<0.0001$ & $<0.0001$ \\
\hline $\mathrm{OPN}^{+}$ & $99(54)$ & $89(91)$ & & \\
\hline c-erbB-2 ${ }^{-}$ & $149(78)$ & $73(74)$ & 0.46 & 1.00 \\
\hline c-erbB-2 ${ }^{+}$ & $42(22)$ & $26(26)$ & & \\
\hline c-erbB-3 ${ }^{-}$ & $83(44)$ & $34(34)$ & 0.13 & 0.90 \\
\hline c-erbB-3 ${ }^{+}$ & $107(56)$ & $65(66)$ & & \\
\hline $\mathrm{S} 100 \mathrm{~A} 4^{-}$ & $141(73)$ & $36(35)$ & $<0.0001$ & $<0.0001$ \\
\hline${\mathrm{S} 100 \mathrm{~A} 4^{+}}^{+}$ & $52(27)$ & $66(65)$ & & \\
\hline $\mathrm{S} 100 \mathrm{P}^{-}$ & $102(58)$ & $16(20)$ & $<0.0001$ & $<0.0001$ \\
\hline $\mathrm{S}_{100 \mathrm{P}^{+}}$ & $75(42)$ & $65(80)$ & & \\
\hline $\mathrm{PgR}^{-}$ & $109(59)$ & $65(66)$ & 0.3 & 1.00 \\
\hline $\mathrm{PgR}^{+}$ & $76(41)$ & $34(34)$ & & \\
\hline $\mathrm{p} 53^{-}$ & $119(61)$ & $53(52.5)$ & 0.17 & 0.95 \\
\hline${\mathrm{p} 53^{+}}^{+}$ & $75(39)$ & $48(47.5)$ & & \\
\hline Cathepsin $D^{-}$ & $27(17.5)$ & $14(18)$ & 1.00 & 1.00 \\
\hline Cathepsin $\mathrm{D}^{+}$ & $127(82.5)$ & $65(82)$ & & \\
\hline $\mathrm{pS}^{-}$ & $107(55)$ & $62(63)$ & 0.26 & 0.99 \\
\hline $\mathrm{pS2}^{+}$ & 87 (45) & 37 (37) & & \\
\hline $\mathrm{ER} \alpha^{-}$ & $82(42)$ & $55(56)$ & 0.036 & 0.44 \\
\hline $\mathrm{ER} \alpha^{+}$ & $112(58)$ & $44(44)$ & & \\
\hline AGR2- & $81(44)$ & $11(12)$ & $<0.0001$ & $<0.0001$ \\
\hline $\mathrm{AGR2}^{+}$ & $104(56)$ & $83(88)$ & & \\
\hline FANCD2 $^{-}$ & $41(24)$ & $62(63)$ & $<0.0001$ & $<0.0001$ \\
\hline FANCD2 $^{+}$ & $133(76)$ & 37 (37) & & \\
\hline $\mathrm{CK} 5 / 6^{-}$ & $161(83)$ & $43(42)$ & $<0.0001$ & $<0.0001$ \\
\hline $\mathrm{CK} 5 / 6^{+}$ & $34(17)$ & 59 (57) & & \\
\hline
\end{tabular}

*LN, lymph node with (+) tumor or without (-) tumor deposits; grade, histological grades I and II versus histological grade III; tumor size $>5 \mathrm{~cm}$ versus $<5 \mathrm{~cm}$ in diameter; other tumor variables, presence $(+)$ or absence $(-)$ of IHC staining for molecular variables using $5 \%$ cutoff for $(+)$ versus $(-)$ staining class for OPN (osteopontin), ER $\alpha$ (estrogen receptor $\alpha$ ), PgR (progesterone receptor), S100P, S100A4, c-erbB-2, c-erbB-3, p53, pS2, and using a 1\% cutoff for $(+)$ versus $(-)$ staining for FANCD2, AGR2, cathepsin D, CK5/6.

${ }^{+}$Number (and percentage) of patients with carcinomas classified as stained or unstained for CK 14 using a $1 \%$ cutoff.

FProbability P from Fisher's Exact test (two sided values), either uncorrected or corrected using the Holm-Bonferroni correction calculated as 1 - (1 $P)^{n}$, where $n=16$ (see further under Materials and Methods). 
Table 4. IHC Staining for Basal Cytokeratins and Metastasis-Inducing Proteins of the Same Area of Tumor for Carcinomas Classified either as Borderline or Positive Staining for CK5/6

\begin{tabular}{|c|c|c|c|c|c|c|}
\hline \multirow[b]{3}{*}{ Tumor variable* } & \multicolumn{6}{|c|}{ Carcinoma cells stained $(\%)^{\dagger}$} \\
\hline & \multicolumn{3}{|c|}{ Borderline staining carcinoma for $\mathrm{CK} 5 / 6$} & \multicolumn{3}{|c|}{ Positive staining carcinoma for CK5/6 } \\
\hline & Focal $^{\ddagger}$ & Adjacent $^{\ddagger}$ & $P$ value ${ }^{\S}$ & Enhanced $^{\ddagger}$ & Adjacent $^{\ddagger}$ & $P$ value ${ }^{\S}$ \\
\hline $\begin{array}{l}\text { CK5/6 } \\
P \text { value }\end{array}$ & $\begin{array}{c}12.3 \pm 1.0 \\
\mathrm{NA}\end{array}$ & $\begin{array}{c}2.6 \pm 0.1 \\
N A\end{array}$ & 0.0033 & $\begin{array}{c}55.4 \pm 5.7 \\
\text { NA }\end{array}$ & $\begin{array}{c}28.7 \pm 0.5 \\
\mathrm{NA}\end{array}$ & 0.014 \\
\hline $\begin{array}{l}\text { CK14 } \\
\quad P \text { value }\end{array}$ & $\begin{array}{c}9.4 \pm 1.0 \\
0.024\end{array}$ & $\begin{array}{c}1.7 \pm 0.2 \\
0.0022\end{array}$ & 0.0002 & $\begin{array}{c}58.6 \pm 1.5 \\
0.40\end{array}$ & $\begin{array}{c}43.6 \pm 3.2 \\
0.013\end{array}$ & 0.008 \\
\hline $\begin{array}{l}\text { FANCD2 } \\
P \text { value }\end{array}$ & $\begin{array}{l}1.1 \pm 0.2 \\
<0.0001\end{array}$ & $\begin{array}{c}0.82 \pm 0.4 \\
0.0022\end{array}$ & 0.36 & $\begin{array}{c}0.12 \pm 0.11 \\
0.0035\end{array}$ & $\begin{array}{c}0.12 \pm 0.11 \\
<0.0001\end{array}$ & 1.0 \\
\hline $\begin{array}{l}\text { S100A4 } \\
\quad P \text { value }\end{array}$ & $\begin{array}{c}8.6 \pm 0.7 \\
0.0063\end{array}$ & $\begin{array}{l}3.3 \pm 0.8 \\
0.27\end{array}$ & 0.001 & $\begin{array}{c}15.6 \pm 1.5 \\
0.0003\end{array}$ & $\begin{array}{c}12.8 \pm 1.9 \\
0.0002\end{array}$ & 0.12 \\
\hline $\begin{array}{l}\text { OPN } \\
P \text { value }\end{array}$ & $\begin{array}{c}20.9 \pm 2.3 \\
0.004\end{array}$ & $\begin{array}{c}30.6 \pm 3.8 \\
0.0061\end{array}$ & 0.019 & $\begin{array}{c}34.8 \pm 3.2 \\
0.0055\end{array}$ & $\begin{array}{c}27.7 \pm 3.5 \\
0.67\end{array}$ & 0.061 \\
\hline $\begin{array}{l}\text { AGR2 } \\
\quad P \text { value }\end{array}$ & $\begin{array}{c}3.2 \pm 0.3 \\
0.0001\end{array}$ & $\begin{array}{c}3.6 \pm 0.5 \\
0.027\end{array}$ & 0.30 & $\begin{array}{c}26.2 \pm 3.7 \\
0.0017\end{array}$ & $\begin{array}{c}35.8 \pm 4.2 \\
0.097\end{array}$ & 0.041 \\
\hline $\begin{array}{l}\text { S100P } \\
P \text { value }\end{array}$ & $\begin{array}{c}29.7 \pm 3.6 \\
0.0013\end{array}$ & $\begin{array}{l}9.1 \pm 0.6 \\
<0.0001\end{array}$ & 0.006 & $\begin{array}{c}9.5 \pm 0.3 \\
0.005\end{array}$ & $\begin{array}{c}9.5 \pm 1.5 \\
0.0008\end{array}$ & 1.0 \\
\hline
\end{tabular}

* $\mathrm{HC}$ staining for cytokeratins 5/6 or 14 (CK5/6 or CK14), FANCD2, S100A4, osteopontin (OPN), anterior gradient 2 protein (AGR2), and S100P.

${ }^{\dagger}$ Mean percentage \pm SD of stained carcinoma cells from five counts of two serial adjacent sections immunohistochemically stained for each tumor variable.

\#The same focal positive/enhanced staining area or the same near-adjacent area.

§Significance of the difference between CK5/6 focal/enhanced and adjacent staining areas for IHC staining for each tumor variable (Student's $t$-test, two sided)

"Significance of the difference between staining for each tumor variable and that for CK5/6 in the same area (Student's $t$-test, two sided).

NA, not applicable.

AGR2 (corrected $P=0.010$ ). The overall association of staining for CK5/6, the four MIPS, and no staining for FANCD2 in 223 complete cases was highly significant in Kendall's concordance test $\left(W=0.147, \chi^{2}=196.4,6 \mathrm{df}\right.$, $P<0.001)$.

To determine whether there was coexpression of the basal cytokeratins and the MIPs, two breast carcinomas were chosen that showed either borderline staining or positive staining for CK5/6 and these were immunohistochemically restained for the basal cytokeratins and for FANCD2 and the four MIPs. Exactly the same areas were examined for each antigen (see Supplemental Figure S2, $\mathrm{C}$ and D, at http://ajp.amjpathol.org). The percentage of stained cells in the focally stained area for CK5/6 was significantly different for all of the MIPs (Student's $t$-test, $P \leq 0.0063$ ), with two showing significantly higher percentages (OPN, S100P) and two showing significantly lower percentages (S100A4, AGR2), and even that for CK14 was just significantly different (Table 4). Although the percentage of stained cells was often significantly lower for the MIPs in the same near-adjacent area $(P \leq$ 0.019 , except AGR2 $P=0.3$ ), the percentage of stained cells for CK5/6 and for the MIPs (except S100A4 $P=$ $0.27)$ were significantly different $(P<0.027)$. Similar significant differences for staining for $\mathrm{CK} 5 / 6$ and for the MIPs were observed in an enhanced staining area of a positively staining tumor for $\mathrm{CK} 5 / 6(P \leq 0.0055)$ and to a lesser extent in the same near-adjacent area $(P \leq 0.0008$ for S100A4, S100P; but OPN, AGR2 $P \geq 0.67)$. There was also much less difference between the enhanced and adjacent staining groups for $\mathrm{CK} 5 / 6(P=0.014)$ and the MIPs $(P \geq 0.041)$ in this $C K 5 / 6$ positively staining carcinoma (Table 4$)$. The percentage of carcinoma cells staining for FANCD2 was extremely low: $\leq 1 \%$ in the borderline and nonexistent in the positively staining carcinomas
(Table 4). Coimmunostaining for CK5/6 and S100A4 did occur in some cells (see Supplemental Figure S2E at http://ajp.amjpathol.org), but these were usually in a minority (see Supplemental Figure S2F at http://ajp. amjpathol.org).

\section{Staining for Other Tumor Variables and Patient Survival}

In addition to staining for CK5/6 and CK14, the other primary tumor variables that showed a significant association with duration of survival for this group of patients at the same census date were nodal status, histological grade, tumor size, and immunocytochemical staining for OPN, c-erbB-2, S100A4, S100P, PgR, p53, ER $\alpha$, AGR2, and FANCD2. The association of staining of the primary tumor for c-erbB-3, cathepsin D, and pS2 with duration of survival failed to reach statistical significance in this group of patients (see Supplemental Table S1 at http:// ajp.amjpathol.org). Most of the primary tumor variables were associated in a negative manner with duration of survival; however, staining of the primary tumors for $\mathrm{ER} \alpha$, FANCD2, and PgR all showed a positive association (see Supplemental Table S1 at http://ajp.amjpathol.org). Staining of the primary tumor for either cytokeratin showed a similar significant association $(P<0.0001)$ and $\mathrm{RR}(5.6$ to $5.7)$ to that for S100A4, S100P, OPN, AGR2, and loss of FANCD2 (see Supplemental Table S1 at http://ajp. amjpathol.org). The highly significant association of staining for either CK5/6 or CK14 with time to patient death was also maintained in lymph node-negative $\left(\chi^{2}=28.1\right.$ or 25.4, $1 \mathrm{df}, P<0.001)$ and lymph node-positive patients $\left(\chi^{2}=21.8\right.$ or 19.2, $\left.1 \mathrm{df}, P<0.001\right)$, in ER $\alpha$ negative $\left(\chi^{2}=28.2\right.$ or $\left.42.2,1 \mathrm{df}, P<0.001\right)$ and $\mathrm{ER} \alpha$ - 
Table 5. Summary of Results for Cox's Proportional Hazards Model for Cancer-Related Deaths

\begin{tabular}{|c|c|c|c|c|c|c|}
\hline Tumor variable* & Coeff $\beta^{\dagger}$ & SE of $\beta$ & $x^{2 \ddagger}$ & $P \S$ & $\mathrm{RR}^{\text {ๆ }}$ & $95 \% \mathrm{Cl}^{\pi}$ \\
\hline \multicolumn{7}{|l|}{ Set A } \\
\hline Lymph nodes & 0.708 & 0.272 & 6.76 & 0.009 & 2.03 & $1.19-3.46$ \\
\hline FANCD2 & -0.965 & 0.288 & 11.20 & 0.001 & 0.381 & $0.216-0.670$ \\
\hline AGR2 & 2.412 & 0.639 & 14.24 & $<0.001$ & 11.15 & $3.19-39.0$ \\
\hline S100P & 0.920 & 0.331 & 7.72 & 0.005 & 2.51 & $1.31-4.80$ \\
\hline OPN & 2.54 & 1.051 & 5.85 & 0.016 & 12.69 & $1.62-99.5$ \\
\hline $\mathrm{ER} \alpha$ & -0.622 & 0.274 & 5.17 & 0.023 & 0.537 & $0.314-0.918$ \\
\hline c-erbB-2 & 1.324 & 0.315 & 17.67 & $<0.001$ & 3.76 & 2.03-6.96 \\
\hline CK5/6 & 0.612 & 0.287 & 4.54 & 0.033 & 1.84 & $1.05-3.24$ \\
\hline \multicolumn{7}{|l|}{ Set B } \\
\hline Tumor size & 0.472 & 0.238 & 3.92 & 0.048 & 1.60 & $1.00-2.56$ \\
\hline Lymph nodes & 0.571 & 0.211 & 7.29 & 0.007 & 1.77 & $1.17-2.68$ \\
\hline CK5/6 & 1.210 & 0.245 & 24.39 & $<0.001$ & 3.35 & $2.07-5.42$ \\
\hline CK14 & 0.912 & 0.238 & 14.63 & $<0.001$ & 2.49 & $1.56-3.97$ \\
\hline
\end{tabular}

For all variables in set $\mathrm{A}$, overall $\chi^{2}=127.711,8 \mathrm{df}, P<0.001$; residual $\chi^{2}=12.316,6 \mathrm{df}, P=0.055$. For pathological variables, CK5/6 and $\mathrm{CK} 14$ in set $\mathrm{B}$, overall $\chi^{2}=99.639,4 \mathrm{df}, P<0.001$, residual $\chi^{2}=1.369,1 \mathrm{df}, P=0.24$ for histological grade.

*In set $A$, all tumor variables that showed a statistically significant association with duration of patient survival times in the univariate analysis for 137 patient cases available with full data sets were included. Thus comparisons between patients with involved lymph nodes, all tumor sizes ( $T_{1}$ to $\left.T_{4}\right)$, all histological grades (I to III), staining for OPN, c-erbB-2, S100A4, S100P, p53, PgR, ER $\alpha$, AGR2, FANCD2, CK5/6, and CK14 were made. In set B, data for pathological tumor variables, involved lymph nodes, all tumor sizes, all histological grades and only staining for CK5/6 and CK14 were included for 199 patients with full data sets.

†Value of $\beta$ parameter $\left(=\log _{\mathrm{e}} \mathrm{RR}\right.$ ) in Cox's multiple regression analysis (see further under Materials and Methods)

${ }^{\ddagger}$ Cox's statistic $\chi^{2}$.

\$Probability $P$ from Cox's statistic $\chi^{2}, 1 \mathrm{df}$ in each case.

"RR for survival and $95 \% \mathrm{Cl}$ from multivariate analysis.

positive patients ( $\chi^{2}=43.4$ or $\left.29.6,1 \mathrm{df}, P<0.001\right)$, and in triple-negative patients $\left(\chi^{2}=69.1\right.$ or $19.3,1 \mathrm{df}, P<$ 0.001).

To determine whether the 14 tumor variables that were significant in the univariate analyses were independent of one another, they were all included in Cox's multivariate regression analysis for the 137 patients with full data sets available (as described under Materials and Methods). The first variable to emerge was staining for FANCD2, followed by staining for S100P, OPN, c-erbB-2, AGR2, $\mathrm{CK} 5 / 6$, nodal status, and ER $\alpha$ (Cox's statistics, $P<$ 0.001). In the multivariate analysis, the individual contributions that staining for CK5/6 made to the RR for duration of survival of the patients was significant $(P=0.033)$ with $R R=1.8$, but that for CK14 was lost (Table 5A). The pathological variables histological grade and tumor size were eliminated from the final equation in the stepwise analysis. If staining for $\mathrm{CK} 5 / 6$ and $\mathrm{CK} 14$ and only the pathological variables were entered into the multivariate analysis, staining for both $\mathrm{CK} 5 / 6$ and $\mathrm{CK} 14$, together with nodal status and tumor size, were independently significantly associated with time to patient death, but histological grade was not (Table 5B). If either cytokeratin was omitted, the other assumed an increased significant association with time to patient death $\left(\mathrm{CK} 5 / 6 \chi^{2}=54.24,1\right.$ $\mathrm{df}, \mathrm{RR}=5.1$ or $\mathrm{CK} 14 \chi^{2}=45.59,1 \mathrm{df}, \mathrm{RR}=4.3$ ), but histological grade was still eliminated (CK5/6 $\chi^{2}=0.62$, $1 \mathrm{df}, P=0.43$ or CK14 $\chi^{2}=2.14,1 \mathrm{df}, P=0.14$ ), suggesting that high grade was confounded by staining for either cytokeratin.

\section{Discussion}

The purpose of the present study was to identify a high-risk subgroup of basal-like breast carcinomas us- ing IHC staining for the basal cell keratins CK5/6 and CK14 $4,5,8,11,30-34$ and then to relate them to the high-risk subgroup of metastasis-inducing proteins in the same cohort of breast cancer patients. ${ }^{17-20} \mathrm{IHC}$ staining of this cohort of 297 breast carcinomas for CK5/6 and separately for CK 14 stained $31 \%$ and $34 \%$, respectively, of the primary tumors, with a $1 \%$ cutoff of stained carcinoma cells to separate the two categorical groups. These percentages agree well with the 38\% reported for CK5, CK 14 , and/or CK $17^{31}$ and $28 \%$ for CK5/6 and/or CK $14^{8}$ in studies using similar $\mathrm{IHC}$ techniques. The lower value of $14 \%$ to $19 \%$ for breast carcinomas stained for CK5/6, CK17, or CK14 $7,9,11$ has been obtained with higher cutoff thresholds of at least $5 \%$ stained carcinoma cells, which translates into $17.5 \%$ of tumors stained for CK14 in the present group of breast carcinomas (see Supplemental Table S1 at http://ajp. amjpathol.org). The basal-like tumors defined by gene expression signatures ${ }^{3}$ may not equate completely to those basal-like tumors defined by IHC-detectable levels of basal cell keratins alone.

Here, we show that the overall duration of survival of patients with positively stained carcinomas was highly significantly worse than for those patients classified as not staining for either CK5/6 or CK14 (Figure 2, A and B), in agreement with results of van de Rijn et $\mathrm{al}^{11}$ and $\mathrm{Abd}$ El-Rehim et al. ${ }^{8}$ This highly significant association of staining for CK5/6 or CK14 with time to patient death is independent of lymph node or ER $\alpha$ status and also occurs in triple-negative patients. ${ }^{30,35}$ If the definition of $\mathrm{IHC}$-detectable basal-like tumors is refined still further by excluding tumors staining for $\mathrm{ER} \alpha$ and/or c-erbB-2 from the CK5/6 staining series, ${ }^{9}$ then the fraction of $\mathrm{IHC}$-detectable basal-like tumors falls to $15 \%$, but it still shows a difference in duration of survival times compared with the 
remainder (Wilcoxon $\chi^{2}=23.9,1 \mathrm{df}, P<0.001 ; \mathrm{RR}=$ $3.0,95 \% \mathrm{Cl}=1.9$ to 4.8 ) and with the luminal $\mathrm{ER} \alpha$ positive, c-erbB-2-negative subtype $\left(\chi^{2}=21.92,1 \mathrm{df}\right.$, $P=<0.001 ; \mathrm{RR}=3.6,95 \% \mathrm{Cl}=2.2$ to 5.9 ), in agreement with previous reports by others. ${ }^{9,33-38}$

Our series of breast cancer patients is not entirely typical of more recent consecutive series of invasive breast cancers, ${ }^{8}$ because our series was collected 25 to 30 years ago in symptomatic clinics, before breast screening programs and when the average tumor size was $>3.5 \mathrm{~cm}$ in diameter at presentation, suggesting that disease in our patients may, on average, be more advanced in time than that of more recent studies (such as those of Rakha et al, ${ }^{39}$ with an average tumor diameter of $1.8 \mathrm{~cm}$ ). This more advanced nature may be reflected in the higher percentage of cases with involved lymph nodes and lower ER $\alpha$ positivity. Moreover, we have excluded cases with distant metastases, which may have reduced the proportion of grade III tumors in our particular series and thereby also reduced the significance of the correlation between basal $\mathrm{IHC} /$ cytokeratin positivity and histological grade, compared with that of others. ${ }^{8}$ Our proportions of $26 \%$ grade III and $48 \%$ with involved lymph nodes agree reasonably well with similar stage I and stage II operable breast cancers collected at comparable dates, with $30 \%$ grade $1 \mathrm{II}$ and $45 \%$ tumors with involved lymph nodes ${ }^{40}$ versus $48 \%$ with grade III and $36 \%$ tumors with involved lymph nodes collected 10 to 15 years later. ${ }^{8}$ Moreover, although our proportion of $53 \%$ $\mathrm{ER} \alpha$-positive tumors is lower than that of later patient groups (eg, 69\% was reported by Abd El-Rehim et al ${ }^{8}$ ) using similar $\mathrm{IHC}$ methods, it is consistent with $57 \%$ positive tumors being found by competitive inhibition of ligand binding for nearly the same group of patients ${ }^{41}$ and is validated by the same $\mathrm{IHC}$ assay finding a higher proportion ( $70 \%$ positive tumors) in our own later group of patients. ${ }^{42}$

When those tumor variables that show a significant correlation with duration of patient survival times in this group of breast cancer patients (see Supplemental Table $\mathrm{S} 1$ at $h$ ttp://ajp.amjpathol.org) were tested for association with $\mathrm{IHC}$ staining for $\mathrm{CK} 5 / 6$ or $\mathrm{CK} 14$ in the primary carcinomas, positive staining for the four MIPs OPN, S100A4, S100P, and AGR2 and no staining for FANCD2 were most significantly associated with positive staining for CK5/6 or for CK14 (corrected $P \leq 0.0007$ ); the other tumor variables tested, including c-erbB-2 and $\mathrm{ER} \alpha$, failed to show any significant association with either cytokeratin (Tables 1 and 3). These results are independent of basal cell keratin or cutoff used, and when these variables are ranked together, they are found to be highly significantly concordant $(P<0.001)$. This association holds largely in patients with $\mathrm{ER} \alpha$-negative, ER $\alpha$-positive, and triple-negative tumors (see Supplemental Table S3 at http://ajp.amjpathol.org). These results demonstrate that positive MIPs and negative FANCD2 are most closely associated with the IHC-detectable basal-like and not the subgroups containing $\mathrm{IHC}$-detectable $\mathrm{ER} \alpha$ or c-erbB2. ${ }^{30,35-38,43}$ However, in two carcinomas in which positive staining for the cytokeratins and MIPs occurred, there was no significant spatial relationship between a staining focus for CK5/6 (or CK14) and the occurrence of a staining focus for any of the MIPs (Table 4), nor was costaining of the same carcinoma cell common in the tumors (see Supplemental Figure S2F at http://ajp.amjpathol.org). Similar results were obtained with five other carcinomas examined (data not shown). These results suggest that there is no simple mechanistic link between expression of basal cytokeratins and the MIPs, such as common regulatory molecules which promote expression of all these genes. Other explanations need to be considered.

The reduction of FANCD2 in the subgroup of $\mathrm{IHC}$ detectable basal-like breast carcinomas is consistent with the finding that the gene expression signature of the basal-like subgroup and that of BRCA1-related breast cancers are strongly correlated at the level of the tumor, ${ }^{38}$ because BRCA1 and FANCD2 interact functionally, and an impediment of either molecule will lead to a failure in the same process of DNA damage repair. ${ }^{44}$ Moreover, both cytogenetic and comparative genomic hybridization analyses suggest that breast carcinomas that express stratified epithelial cytokeratins also possess increased genomic abnormalities, ${ }^{45,46}$ a fact consistent with our findings and likewise pointing to a common defective DNA repair process. Our results therefore raise the possibility that the underlying mechanism responsible for the enhanced expression of the basal cytokeratins here and of the four MIPs in a previous publication ${ }^{22}$ is related to a decrease in overall FANCD2. Although strong clustering of staining for CK5/6, CK14, and the four MIPs and lack of staining for FANCD2 has been identified in this group of breast carcinomas, this would appear not to reflect coexpression (or lack of coexpression for FANCD2) of these molecules within the same carcinoma cells (Table 4). Thus, the changed expression of these molecules is unlikely to be related to simple biochemical pathways or transcriptional events, but rather to a changed probability of expression in particular tumors, perhaps related to a subgroup of breast cancers with an underlying genetic flexibility/instability. Direct interrogation of published data sets of mRNA profiles from large studies using expression microarrays does not sort MIP/ FANCD2 expression into the GE basal or other GE classifications of breast cancer. ${ }^{47-49}$ This result may be due to incomplete data on expression of the MIPs/ FANCD2 $2^{47,48}$ and/or the lack of correlation between levels of mRNA and its cognate protein in human breast cancer, as discussed previously. ${ }^{50}$

In addition to the complex of cytokeratins that include CK5/6 and CK 14 being found in basally situated smooth muscle actin/myosin-containing myoepithelial cells, ${ }^{6}$ they are also detected in occasional suprabasal epithelial cells, particularly in growing terminal ductal structures. ${ }^{31,51-53}$ The observations of intermediate cell forms between the more peripheral cells in these structures and the subtending epithelial and myoepithelial cells ${ }^{52,54,55}$ are in line with findings in cultured human breast epithelial cells ${ }^{56,57}$ that a subclass of epithelial-like cells containing basal cell cytokeratins ${ }^{54,55,58}$ progressively differentiates into myoepithelial or into luminal epithelial cells, as reported originally in rodent systems. ${ }^{59-61}$ Thus, the basal-like breast carcinomas may contain the vestiges of 
a normal breast stem cell that has lost its capability to differentiate completely into end-stage myoepithelial cells, ${ }^{58,62,63}$ but still expresses basal cell cytokeratins, ${ }^{64}$ as well as CK19, ${ }^{65,66}$ vimentin, ${ }^{67} \mathrm{CD} 44,{ }^{68} \mathrm{ALDH} 1,{ }^{69}$ and/or CD133. ${ }^{70}$ In support of this hypothesis, the mutant BRCA1 hereditary breast tumors that show a potentially true basal-like GE phenotype ${ }^{38}$ also contain basal cell cytokeratins $^{33}$ and CD44/CD133-overexpressing cells with cancer stem cell characteristics. ${ }^{70}$ Alternatively, a failure in the FA/BRCA tumor suppressor pathway of DNA repair $^{21}$ in a luminal epithelial progenitor ${ }^{58,71}$ may reflect selection for expression of the same or similar genes in BRCA1 hereditary and somatic basal-like GE breast carcinomas. Both models are consistent with wild-type BRCA1 stimulating expression of $\mathrm{ER} \alpha$ and repressing basal cell cytokeratin markers and with reduction or mutation in BRCA1 reversing these events, ${ }^{72-74}$ similar to their reciprocal effect on the OPN promoter. ${ }^{75}$

The above two models may not be mutually exclusive. Although vimentin and CK14 are expressed mainly in the mammary stem cell enriched population ${ }^{58}$ and in basallike GE and mutant BRCA1 inherited breast cancers, ${ }^{30,33}$ signature genes of the luminal epithelial progenitors are reported to be more associated with basal-like GE and mutant BRCA1 carcinomas. ${ }^{58,71}$ Thus, there may be a degree of flexibility in expression of the carcinoma cells in the basal-like GE tumors that allows expression of genes related to both mammary stem and luminal epithelial progenitor cells. ${ }^{71}$ This flexibility in expression may arise either by reversible cellular interconversions between mammary stem cells and epithelial progenitor cells ${ }^{76}$ or by genome destabilization caused by a deficiency in the FA/BRCA pathway. ${ }^{21,22,74}$ Whatever the model, we have shown that proteins that can induce metastasis ${ }^{14-17}$ in rat breast cells ${ }^{13,59}$ are also highly significantly associated with this prognostically unfavorable subgroup of basal cell CK-containing breast carcinomas and therefore may be the cause of their metastatic spread and consequent death in humans.

\section{Acknowledgments}

We thank Christopher Holcombe and the staff of the Breast Unit, Royal Liverpool University Hospital, for clinical assistance; Dr. Evelyn Williams and the staff of the North West Intelligence Service (Liverpool Office) for providing patient outcome data; and Anne Salisbury, Natalie Stephenson, Rachel Thomas, Donna Topping, and Matthew Cullen for help in data collection.

\section{References}

1. Wellings SR, Jensen HM, Marcum RG: An atlas of subgross pathology of the human breast with special reference to possible precancerous lesions. J Natl Cancer Inst 1975, 55:231-273

2. Page DL, Anderson TJ: Diagnostic Histopathology of the Breast. Churchill Livingstone, Edinburgh, 1988

3. Sorlie T, Tibshirani R, Parker J, Hastie T, Marron JS, Nobel A, Deng S, Johnsen H, Pesich R, Geisler S, Demeter J, Perou CM, Lønning PE, Brown PO, Børresen-Dale AL, Botstein D: Repeated observation of breast tumor subtypes in independent gene expression data sets Proc Natl Acad Sci USA 2003, 100:8418-8423

4. Moll R, Franke WW, Schiller DL, Geiger B, Krepler R: The catalog of human cytokeratins: patterns of expression in normal epithelia, tumors and cultured cells. Cell 1982, 31:11-24

5. Dairkee SH, Mayall BH, Smith HS, Hackett AJ: Monoclonal marker that predicts early recurrence of breast cancer. Lancet 1987, 1(8531):514

6. Gusterson BA, Warburton MJ, Mitchell D, Ellison M, Neville AM Rudland PS: Distribution of myoepithelial cells and basement membrane proteins in the normal breast and in benign and malignant breast disease. Cancer Res 1982, 42:4763-4770

7. Rudland PS, Leinster SJ, Winstanley J, Green B, Atkinson A, Zakhour $\mathrm{H}$ : Immunocytochemical identification of cell types in benign and malignant breast diseases: variations in cell markers accompany the malignant state. J Histochem Cytochem 1993, 41:543-553

8. Abd El-Rehim DM, Pinder SE, Parish CE, Bell J, Blamey RW, Robertson JFR, Nicholson RI, Ellis IO: Expression of luminal and basal cytokeratins in human breast carcinoma. J Pathol 2004, 203:661-671

9. Nielsen TO, Hsu FD, Jensen K, Cheong M, Karaca G, Hu Z, Hernandez-Boussard T, Livsey C, Cowan D, Dressler L, Akslen LA, Ragaz J, Gown AM, Gilks CB, van de Rijn M, Perou CM: Immunohistochemical and clinical characterisation of the basal-like subtype of invasive breast carcinoma. Clin Cancer Res 2004, 10:5367-5374

10. Malzahn K, Mitze M, Thoenes M, Moll R: Biological and prognostic significance of stratified epithelial cytokeratins in infiltrating breast carcinomas. Virchows Arch 1998, 433:119-129

11. van de Rijn M, Perou CM, Tibshirani $R$, Haas $P$, Kallioniemi $O$, Kononen J, Torhorst J, Sauter G, Zuber M, Köchli OR, Mross F, Dieterich H, Seitz R, Ross D, Botstein D, Brown P: Expression of cytokeratins 17 and 5 identifies a group of breast carcinomas with poor clinical outcome [Erratum appeared in Am J Pathol 2003, 163: 377]. Am J Pathol 2002, 161:1991-1996

12. Fan C, Oh DS, Wessels L, Weigelt B, Nuyten DSA, Nobel AB, van't Veer LJ, Perou CM: Concordance among gene-expression-based predictors for breast cancer. N Engl J Med 2006, 355:560-569

13. Dunnington DJ, Monaghan P, Hughes CM, Rudland PS: Phenotypic instability of rat mammary tumor epithelial cells. J Natl Cancer Inst 1983, 71:1227-1240

14. Davies BR, Davies MPA, Gibbs FM, Barraclough R, Rudland PS: Induction of the metastatic phenotype by transfection of a benign rat mammary epithelial cell line with the gene for $\mathrm{p} 9 \mathrm{Ka}$, a rat calciumbinding protein, but not with the oncogene EJ-ras-1. Oncogene 1993, 8:999-1008

15. Oates AJ, Barraclough R, Rudland PS: The identification of osteopontin as a metastasis-related gene product in a rodent mammary tumour model. Oncogene 1996, 13:97-104

16. Liu D, Rudland PS, Sibson DR, Platt-Higgins A, Barraclough R: Human homologue of cement gland protein, a novel metastasis inducer associated with breast carcinomas. Cancer Res 2005, 65:3796-3805

17. Wang G, Platt-Higgins A, Carroll J, de Silva Rudland S, Winstanley J, Barraclough R, Rudland PS: Induction of metastasis by S100P in a rat mammary model and its association with poor survival of breast cancer patients. Cancer Res 2006, 66:1199-1207

18. Rudland PS, Platt-Higgins A, Renshaw C, West CR, Winstanley JHR, Robertson L, Barraclough R: Prognostic significance of the metastasis-inducing protein S100A4 (p9Ka) in human breast cancer. Cancer Res 2000, 60:1595-1603

19. Rudland PS, Platt-Higgins A, El-Tanani M, de Silva Rudland S, Barraclough $\mathrm{R}$, Winstanley $\mathrm{JHR}$, Howitt $\mathrm{R}$, West CR: Prognostic significance of the metastasis-associated protein osteopontin in human breast cancer. Cancer Res 2002, 62:3417-3427

20. Barraclough DL, Platt-Higgins A, de Silva Rudland S, Barraclough R, Winstanley J, West CR, Rudland PS: The metastasis-associated anterior gradient 2 protein is correlated with poor survival of breast cancer patients. Am J Pathol 2009, 175:1848-1857

21. Wang W: Emergence of DNA-damage response network consisting of Fanconi anemia and BRCA proteins. Nat Rev Genet 2007, 8:735-748

22. Rudland PS, Platt-Higgins AM, Davies LM, de Silva Rudland S, Wilson JB, Aladwani A, Winstanley J, Barraclough DL, Barraclough R, West CR, Jones NJ: Significance of the Fanconi anemia FANCD2 protein in sporadic and metastatic human breast cancer. Am J Pathol 2010, 176:2935-2947 
23. Purkis PE, Steele JB, Mackenzie IC, Nathrath WB, Leigh IM, Lane EB: Antibody markers of basal cells in complex epithelia. J Cell Sci 1990, 97:39-50

24. de Silva Rudland S, Martin L, Roshanlall C, Winstanley J, Leinster S, Platt-Higgins A, Carroll J, West C, Barraclough R, Rudland P: Association of S100A4 and osteopontin with specific prognostic factors and survival of patients with minimally invasive breast cancer. Clin Cancer Res 2006, 12:1192-1200

25. Platt-Higgins AM, Renshaw CA, West CR, Winstanley JH, De Silva Rudland S, Barraclough R, Rudland PS: Comparison of the metastasis-inducing protein S100A4 (p9Ka) with other prognostic markers in human breast cancer. Int J Cancer 2000, 89:198-208

26. Leake R, Barnes D, Pinder S, Ellis I, Anderson E, Anderson T, Adamson R, Rhodes A, Miller K, Walker R: Immunohistochemical detection of steroid receptors in breast cancer: a working protocol. UK Receptor Group, UK NEQAS, The Scottish Breast Cancer Pathology Group, and The Receptor and Biomarker Study Group of the EORTC. J Clin Pathol 2000, 53:634-635

27. Walker RA, Bartlett JM, Dowsett M, Ellis IO, Hanby AM, Jasani B, Miller K, Pinder SE: HER2 testing in the UK: further update to recommendations. J Clin Pathol 2008, 61:818-824

28. McShane LM, Altman DG, Sauerbrei W, Taube SE, Gion M, Clark GM; Statistics Subcommittee of the NCI-EORTC Working Group on Cancer Diagnostics: REporting recommendations for tumour MARKer prognostic studies (REMARK). Eur J Cancer 2005, 41:1690-1696

29. Conover WJ: Practical Nonparametric Statistics, ed 3. London, Wiley, 1999

30. Rakha EA, Elsheikh SE, Aleskandarany MA, Habashi HO, Green AR, Powe DG, El-Sayed ME, Benhasouna A, Brunet JS, Akslen LA, Evans AJ, Blamey R, Reis-Filho JS, Foulkes WD, Ellis IO: Triple negative breast cancer: distinguishing between basal and nonbasal subtypes. Clin Cancer Res 2009, 15:2302-2310

31. Nagle RB, Böcker W, Davis JR: Characterization of breast carcinomas by two monoclonal antibodies distinguishing myoepithelial from luminal epithelial cells. J Histochem Cytochem 1986, 34:869-881

32. Wetzels RH, Kuijpers HJ, Lane EB, Leigh IM, Troyanovsky SM, Holland R, van Haelst UJ, Ramaekers FC: Basal cell-specific and hyperproliferation-related keratins in human cancer. Am J Pathol 1991 138:751-763

33. Lakhani SR, Reis-Filho JS, Fulford L, Penault-Llorca F, van der Vijver M, Parry S, et al:Breast Cancer Linkage Consortium: Prediction of BRCA1 status in patients with breast cancer using estrogen receptor and basal phenotype. Clin Cancer Res 2005, 11:5175-5180

34. Fulford LG, Easton DF, Reis-Filho JS, Sofronis A, Gillett CE, Lakhan SR, Hanby A: Specific morphological features predictive for the basal phenotype in grade 3 invasive ductal carcinoma of breast. Histopathology 2006, 49:22-34

35. Cheang MC, Voduc D, Bajdik C, Leung S, McKinney S, Chia SK, Perou CM, Nielsen TO: Basal-like breast cancer defined by five biomarkers has superior prognostic value than triple-negative phenotype. Clin Cancer Res 2008, 14:1368-1376

36. Rakha EA, Reis-Filho JS, Ellis IO: Basal-like breast cancer: a critical review. J Clin Oncol 2008, 26:2568-2581

37. Dawson SJ, Provenzano E, Caldas C: Triple negative breast cancers: clinical and prognostic implications. Eur J Cancer 2009, 45 Suppl $1: 27-40$

38. Foulkes WD, Stefansson IM, Chappuis PO, Bégin LR, Goffin JR, Wong N, Trudel M, Akslen LA: Germline BRCA1 mutations and a basal epithelial phenotype in breast cancer. J Natl Cancer Inst 2003, 95:1482-1485

39. Rakha EA, El-Sayed ME, Lee AHS, Elston CW, Grainge MJ, Hodi Z, Blamey RW, Ellis IO: Prognostic significance of the Nottingham histologic grade in invasive breast carcinoma. J Clin Oncol 2008, 26 : 3153-3158

40. Elston CW, Gresham GA, Rao GS, Zebro T, Haybittle JL, Houghton J, Kearney G: The Cancer Research Campaign (King's/Cambridge) Trial for early breast cancer: clinico-pathological aspects. $\mathrm{Br} \mathrm{J}$ Cancer 1982, 45:655-669

41. Winstanley J, Cooke T, Murray GD, Platt-Higgins A, George WD, Holt S, Myskov M, Spedding A, Barraclough BR, Rudland PS: The long term prognostic significance of c-erbB-2 in primary breast cancer. Br J Cancer 1991, 63:447-450

42. Davies MPA, Barraclough DL, Stewart C, Joyce KA, Eccles RM, Barraclough R, Rudland PS, Sibson DR: Expression and splicing of the unfolded response gene XBP-1 are significantly associated with clinical outcome of endocrine-treated breast cancer. Int J Cancer 2008, 123:85-88

43. Podo F, Buydens LM, Degani H, Hilhorst R, Klipp E, Gribbestad IS, Van Huffel S, van Laarhoven HW, Luts J, Monleon D, Postma GJ, Schneiderhan-Marra N, Santoro F, Wouters H, Russnes HG, Sørlie T, Tagliabue E, Børresen-Dale AL; FEMME Consortium: Triple-negative breast cancer: present challenges and new perspectives. Mol Oncol 2010, 4:209-229

44. Taniguchi T, Garcia-Higuera I, Andreassen PR, Gregory RC, Grompe M, D'Andrea AD: S-phase-specific interaction of the Fanconi anemia protein, FANCD2, with BRCA1 and RAD51. Blood 2002, 100:24142420

45. Jones C, Nonni AV, Fulford L, Merrett S, Chagger R, Eusebi U, Lakhani SR: CGH analysis of ductal carcinoma of the breast with basaIoid/myoepithelial cell differentiation. Br J Cancer 2001, 85:422-427

46. Korsching E, Packeisen J, Agelopoulos K, Eisenacher M, Voss R, Isola J, van Diest PJ, Brandt B, Boecker W, Buerger H: Cytogenetic alterations and cytokeratin expression patterns in breast cancer: integrating a new model of breast differentiation into cytogenetic pathways of breast carcinogenesis. Lab Invest 2002, 82:1525-1533

47. Perou CM, Sørlie T, Eisen MB, van de Rijn M, Jeffrey SS, Rees CA, Pollack JR, Ross DT, Johnsen H, Akslen LA, Fluge O, Pergamenschikov A, Williams C, Zhu SX, Lønning PE, Børresen-Dale AL, Brown $\mathrm{PO}$, Botstein D: Molecular portraits of human breast tumours. Nature 2000, 406:747-752

48. Sørlie T, Perou CM, Tibshirani R, Aas T, Geisler S, Johnsen H, Hastie $T$, Eisen MB, van de Rijn M, Jeffrey SS, Thorsen T, Quist $H$, Matese JC, Brown PO, Botstein D, Eystein Lønning P, Børresen-Dale AL: Gene expression patterns of breast carcinomas distinguish tumor subclasses with clinical implications. Proc Natl Acad Sci USA 2001, 98:10869-10874

49. van 't Veer LJ, Dai H, van de Vijver MJ, He YD, Hart AA, Mao M, Peterse HL, van der Kooy K, Marton MJ, Witteveen AT, Schreiber GJ, Kerkhoven RM, Roberts C, Linsley PS, Bernards R, Friend SH: Gene expression profiling predicts clinical outcome of breast cancer. Nature 2002, 415:530-536

50. Barraclough DL, Sewart S, Rudland PS, Shoker BS, Sibson DR, Barraclough R, Davies MP: Microarray analysis of suppression subtracted hybridisation libraries identifies genes associated with breast cancer progression. Cell Oncol 2010, 32:87-99

51. Rudland PS, Hughes CM: Immunocytochemical identification of cell types in human mammary gland: variations in cellular markers are dependent on glandular topography and differentiation. J Histochem Cytochem 1989, 37:1087-1100

52. Rudland PS: Histochemical organization and cellular composition of ductal buds in developing human breasts: evidence for cytological intermediates between epithelial and myoepithelial cells. J Histochem Cytochem 1991, 39:1471-1484

53. Gusterson BA, Ross DT, Heath VJ, Stein T: Basal cytokeratins and their relationship to the cellular origin and functional classification of breast cancer. Breast Cancer Res 2005, 7:143-148

54. Böcker W, Moll R, Poremba C, Holland R, Van Diest PJ, Dervan P, Bürger H, Wai D, Ina Diallo R, Brandt B, Herbst H, Schmidt A, Lerch MM, Buchwallow IB: Common adult stem cells in the human breast give rise to glandular and myoepithelial cell lineages: a new cell biological concept. Lab Invest 2002, 82:737-746

55. Boecker W, Buerger $\mathrm{H}$ : Evidence of progenitor cells of glandular and myoepithelial cell lineages in the human adult female breast epithelium: a new progenitor (adult stem) cell concept. Cell Prolif 2003, 36 Suppl 1:73-84

56. Rudland PS, Ollerhead G, Barraclough R: Isolation of simian virus 40-transformed human mammary epithelial stem cell lines that can differentiate to myoepithelial-like cells in culture and in vivo. Dev Biol 1989, 136:167-180

57. Clayton H, Titley I, Vivanco M: Growth and differentiation of progenitor/stem cells derived from the human mammary gland [Erratum appeared in Exp Cell Res 2004;300:257]. Exp Cell Res 2004, 297: 444-460

58. Lim E, Vaillant F, Wu D, Forrest NC, Pal B, Hart AH, Asselin-Labat ML, Gyorki DE, Ward T, Partanen A, Feleppa F, Huschtscha LI, Thorne HJ, kConFab, Fox SB, Yan M, French JD, Brown MA, Smyth GK, Visvader $\mathrm{JE}$, Lindeman GJ: Aberrant luminal progenitors as the candidate 
target population for basal tumor development in BRCA1 mutation carriers. Nat Med 2009, 15:907-913

59. Bennett DC, Peachey LA, Durbin H, Rudland PS: A possible mammary stem cell line. Cell 1978, 15:283-298

60. Ormerod EJ, Rudland PS: Cellular composition and organisation of ductal buds in developing rat mammary glands: evidence for morphological intermediates between epithelial and myoepithelial cells. Am J Anat 1984, 170:631-652

61. Asselin-Labat ML, Shackleton M, Stingl J, Vaillant F, Forrest NC, Eaves CJ, Visvader JE, Lindeman GJ: Steroid hormone receptor status of mouse mammary stem cells. J Natl Cancer Inst 2006 , 98:1011-1014

62. Rudland PS: Epithelial stem cells and their possible role in the development of the normal and diseased breast. Histol Histopathol 1993 8:385-404

63. Behbod F, Rosen JM: Will cancer stem cells provide new therapeutic targets? Carcinogenesis 2005, 26:703-711

64. Stingl J, Caldas C: Molecular heterogeneity of breast carcinomas and the cancer stem cell hypothesis. Nat Rev Cancer 2007, 7:791-799

65. Petersen OW, Gudjonsson T, Villadsen R, Bissell MJ, Rønnov-Jessen $\mathrm{L}$ : Epithelial progenitor cell lines as models of normal breast morphogenesis and neoplasia. Cell Prolif 2003, 36 Suppl 1:33-44

66. Clarke RB, Spence K, Anderson E, Howell A, Okano H, Potten CS: A putative breast stem cell population is enriched for steroid receptorpositive cells. Dev Biol 2005, 277:443-456

67. Korsching E, Packeisen J, Liedtke C, Hungermann D, Wülfing P, van Diest PJ, Brandt B, Boecker W, Buerger $\mathrm{H}$ : The origin of vimentin expression in invasive cancer: epithelial-mesenchymal transition, myoepithelial histogenesis or histogenesis from progenitor cells with bilinear differentiation potential? J Pathol 2005, 206:451-457

68. Abraham BK, Fritz P, McClellan M, Hauptvogel P, Athelogou M, Brauch H: Prevalence of CD44+/CD24-/low cells in breast cancer may not be associated with clinical outcome but may favor distant metastasis. Clin Cancer Res 2005, 11:1154-1159
69. Ginestier C, Hur MH, Charafe-Jauffret E, Monville F, Dutcher J, Brown M, Jacquemier J, Viens P, Kleer CG, Liu S, Schott A, Hayes D, Birnbaum D, Wicha MS, Dontu G: ALDH1 is a marker of normal and malignant human mammary stem cells and a predictor of poor clinical outcome. Cell Stem Cell 2007, 1:555-567

70. Wright MH, Calcagno AM, Salcido CD, Carlson MD, Ambudkar SV, Varticovski L: Brca1 breast tumors contain distinct CD44 +/CD24and CD133+ cells with cancer stem cell characteristics. Breast Cancer Res 2008, 10:R10

71. Molyneux G, Geyer FC, Magnay FA, McCarthy A, Kendrick H, Natrajan R, Mackay A, Grigoriadis A, Tutt A, Ashworth A, Reis-Filho JS, Smalley MJ: BRCA1 basal-like breast cancers originate from luminal epithelial progenitors and not from basal stem cells. Cell Stem Cell 2010, 7:403-417

72. Hosey AM, Gorski JJ, Murray MM, Quinn JE, Chung WY, Stewart GE, James CR, Farragher SM, Mulligan JM, Scott AN, Dervan PA, Johnston PG, Couch FJ, Daly PA, Kay E, McCann A, Mullan PB, Harkin DP: Molecular basis for estrogen receptor alpha deficiency on BRCA1linked breast cancer. J Natl Cancer Inst 2007, 99:1683-1694

73. Gorski JJ, James CR, Quinn JE, Stewart GE, Staunton KC, Buckley NE, McDyer FA, Kennedy RD, Wilson RH, Mullan PB, Harkin DP: BRCA1 transcriptionally regulates genes associated with the basallike phenotype in breast cancer. Breast Cancer Res Treat 2010, 122:721-731

74. Liu S, Ginestier C, Charafe-Jauffret E, Foco H, Kleer CG, Merajver SD, Dontu G, Wicha MS: BRCA1 regulates human mammary stem cell progenitor cell fate. Proc Natl Acad Sci USA 2008, 105:1680-1685

75. El-Tanani MK, Campbell FC, Crowe P, Erwin P, Harkin DP, Pharoah P, Ponder B, Rudland PS: BRCA1 suppresses osteopontin-mediated breast cancer. J Biol Chem 2006, 281:26587-26601

76. Rudland PS, Barraclough R, Fernig DG, Smith JA: Mammary stem cells in normal development and cancer. Stem Cells. Edited by CS Potten. London, Academic Press, 1996, pp 147-232 